\title{
EFFECT OF THE USE OF VERMICOMPOST AND RHIZOBIAL INOCULATION ON SOME SOIL CHARACTERISTICS, GROWTH AND YIELD OF MUNG BEAN Vigni radiate $L$.
}

\section{J. S. Alkobaisy}

Assis. Prof.

College of Agriculture, University of Anbar ag.jamal.saleh@uoanbar.edu.iq

\section{ABSTRACT}

A field experiment was conducted in silty loam soil to study the effect of vermicompost fertilizer and inoculums Rhizobium legumenosarum on growth and yield of mung bean (Vigni radiate L.), and some soil properties after planting. The experiment consists of nine treatments as follows :T1: control, T2: full recommended mineral fertilizer, T3: vermicompost 8 t.ha $^{-1}$, T4: vermicompost 16 t.ha ${ }^{-1}$, T5: vermicompost 8 t.ha $^{-1}+$ rhizobia, T6: vermicompost16 t.ha ${ }^{-1}+$ rhizobia, T7: vermicompost 2 t.ha ${ }^{-1}+1 / 2$ recommended mineral fertilizer, T8: rhizobia $+1 / 2$ recommended mineral fertilizer, T9: vermicompost 8 t.ha $^{-1}+$ rhizobia $+1 / 2$ recommended mineral fertilizer. The experiment was conducted according to RCBD design with three replications. The results were indicated that the use of vermicompost $16 \mathrm{t}^{-\mathrm{ha}^{-}}$ ${ }^{1}$ with the rhizobia inoculation (T6) has improved some soil properties, as this treatment reduced the pH and EC of the soil to 7.18 and $2.20 \mathrm{dsm}^{-1}$. While CEC and O.M increased to $47.9 \mathrm{Cmole}^{-1}$ and $\mathbf{2 . 9 6 \%}$, respectively. Whereas, the treatment $T 9$ was superior in most of the traits, including plant height $(70.1 \mathrm{~cm})$, Root weight $\left(5.8 \mathrm{~g} \mathrm{plant}^{-1}\right)$ and a number of active and total root nodes $(41.3$ and 36.6 nodes plant ${ }^{-1}$ ). The treatment $\mathrm{T} 9$ also gave the best characteristics of the yield components, including the number of pods plant ${ }^{-1}$, weight of pods plant ${ }^{-1}$, weight 1000 seeds $(\mathrm{g})$, total yield and was 51.0 pods

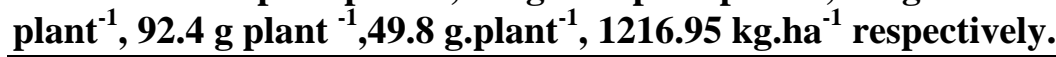

Keywords: effective root nodes, pods, root weight, inoculation

الكبيسي و مطلك

169-163:1 مجلة العلوم الزراعية العراقية - $52: 2021$ (1)

Vigni radiate L تأثير استخدام الفيرميكومبوست ولقاح الرايزوبيا في بعض صفات التربة ونمو وحاصل الماش

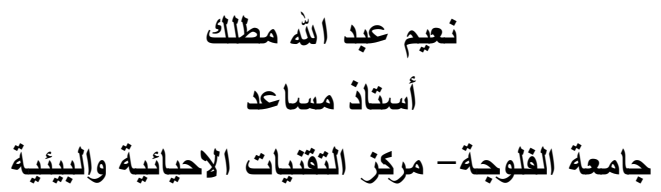

المستخلص

أجريت تجرية حقلية في تريـة مزيجية غرينية لمعرفة تأثير سماد الفيرميكومبوست Vermicompost ولقاح الريزوييا Rhizobium RCBD على نمو وحاصل نبات المساش ويعض صفات التربة بعد الزراعة بتصميم القطاعات العشوائية الكاملـة legumenosarum

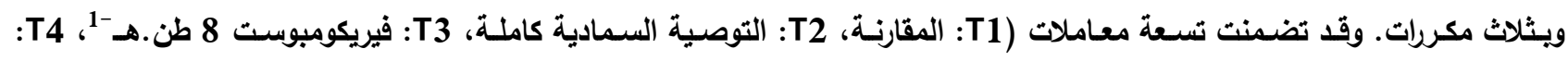

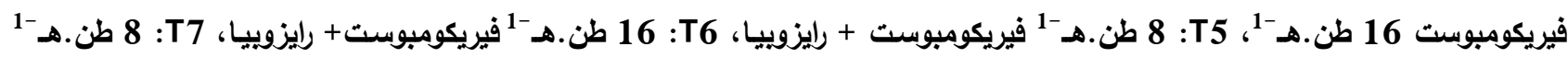

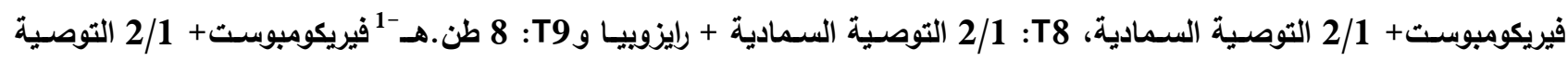
السمادية + رايزوييا). بينت النتائج أن استخدام الفيرميكومبوست بالمستوى الثاني 16 طن. هـ-1 مـ لقاح الرايزوييا (T6) قد حسن من بعض صفات التربـة إذ خفضت هذه المعاملة pH و

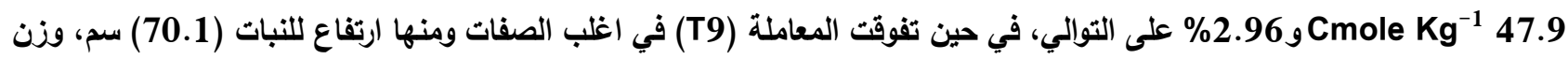
للجذر (5.8 غم نبات -1) وعدد للعقد الجذريـة الكلية والفعالة (41.3 و36.6 عقدة نبات 1 (1). كما أعطت المعاملة T9 أفضل الصفات لمكونات الحاصل ومنها عدد قرنات. نبات -1، وزن قرنات. نبات

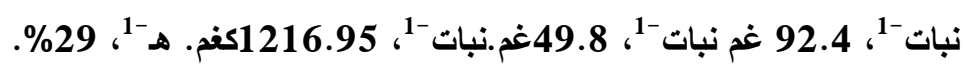
الكلمات المفتاحية: العقد الجذرية الفعالة، العقد الفعالة، وزن الجذر، لقاح الرايزوبيا. 


\section{INTRODUCTION}

Vermicompost (compost from earthworm raised on useless waste such as household and farm waste, office, market, etc.) is used as a biological organic fertilizer in agriculture, it also provide the soil with nutrients, growth regulators and enzymes, to increase the productivity of the crop, it also improves the physical properties of the soil and creates a safe environmental system for food production, as using it can drop out or reduce the use of chemical fertilizers and pesticides that have a negative impact on public health and environmental pollution, as well as producing good-quality natural crops (9). The importance of vermicompost is reflected in the fact that in addition to the presence of organic nitrogen, phosphorus and potassium in it, it is considered a good source for the supply of micronutrients such as iron, manganese, copper, zinc, molybdenum and iodine, and more importantly, the nutrients are released from vermicompost in quantities appropriate to the needs of the plant as a result of microbial activity in the soil and the decomposition of compost (7). The addition of vermicompost improves dry weight, leaf area, chlorophyll content and leaf content of nitrogen, phosphorous and potassium by increasing the level of vermicompost, in addition reducing the negative effect of saline stress (17). The addition of vermicompost improves the quality characteristics of the plant and improves some of the physical, fertile and biological characteristics of the soil as it increases water retention capability and improves porosity and soil ventilation, also the organic matter and increases the effectiveness of beneficial microorganisms in the soil. Activation some biological inoculation, such as bacteria and fungi, with vermicompost will increase the activity of added microorganisms and thus increase their effectiveness and benefit to soil and plants (16). Edwards (11), Hossein et al. (13), and Parveen et al. (25) found that adding vermicompost improved the biological state of the soil by increasing the activity of beneficial bacteria and other beneficial microorganisms in the soil and had an active role in increasing organic matter and the activity of beneficial micro-organisms, and elimination of pathogens, which led to dispensing of chemical control with harmful effects on humans and environmental pollution, this was also confirmed by Abdollah et al.(1), and Javed and Panwar (15). Mung bean (Vigna radiate $\mathrm{L}$ ) is one of the important legume crop and it is main crops in East and South Asia, the cultivation of Mung bean represents about $9 \%$ of the total legumes in the world as it is used as green feed in animal feeding and as a green fertilizer to improve the properties of the soil. In addition to its economic importance, mung bean crop contains many nutrients beneficial to human health, as it contains a high protein percentage that may reach up to $30 \%$ and also contains fiber and many mineral substances such as iron, phosphorus, calcium, magnesium, potassium, copper and some vitamins such as vitamin $\mathrm{C}, \mathrm{B}, \mathrm{E}$ and some acids, it was also found that mung bean leaves provide the soil about $37-40 \mathrm{~kg}$ nitrogen per hectare $(12,15$, 24). This study was aim to evaluate the effect of vermicompost fertilizer and inoculation Rhizobium legumenosarum on growth and yield of mung bean.

\section{MATERIALS AND METHODS}

This experiment was carried out at the agricultural fields in the Al-Sejar area of the Fallujah district, and Table 1 illustrates some of the chemical and physical characteristics of the experimental soil. The experiment was included 9 treatments with in randomized complete block design (RBCD) three replications (Table 2). The experiment at field was divided into plots, with $4 \mathrm{~m}^{2}$ plot size and $1 \mathrm{~m}$ baander between plots to ensure that the inoculation does not mix. Vermicompost (the characteristics show in Table 3) were added and mixed with the soil to a depth of $30 \mathrm{~cm}$ and chemical fertilizers were added according to assigned treatments (Table 2), and fertilizers were added and mixing well with the soil as fertilizers were added in the form of urea $46 \%$ $\mathrm{N}$ and super triphosphate $45 \% \quad \mathrm{P}_{2} \mathrm{O}_{5}$ and potassium sulfate $50 \% \quad \mathrm{~K}_{2} \mathrm{O}$. The bacterial inoculums Rhizobium legumenosarum was activated and mixed with the seeds to be inoculated just before planting. The seeds were sown on 28/3/2019, with 3 seeds in each hole, with a distance of $40 \mathrm{~cm}$ between the lines and $25 \mathrm{~cm}$ between the plants, and then agricultural operations were carried out as, 
weeding until the harvest process on 20/6/2019. Measurements were made before harvest such as plant height, leaf area before the appearance of pods, the number of total and effective root nodes. The harvest was done after ripening of the most pods of the experimental units and took plant samples, yields and soil after planting. In the soil, the following characteristics were estimated: electrical conductivity (EC), $\mathrm{pH}$, total nitrogen, available phosphorous and potassium, Cation Exchange Capacity (CEC), organic matter. Distwent plant traits and yield were studied, namely the weight of the vegetative, the root length, the root weight, the number of pods per plant, pod weight. Plant ${ }^{-1}$, 1000 seeds weight, total yield. $\mathrm{h}^{-1}$ and protein percentage of in the mung bean seed.

Table 1. Chemical and physical properties of the soil before planting.

\begin{tabular}{|ccc|}
\hline Character & Unit & Values \\
\hline Electric Conductivity (EC) $1: 1$ & $\mathbf{d s ~ m}^{-1}$ & 2.65 \\
pH & - & 7.50 \\
Cation Exchange Capacity (CEC) & $\mathrm{Cmole} \mathrm{Kg}^{-1}$ & 22.6 \\
Organic matter (OM) & $\%$ & 1.2 \\
Total nitrogen (N) & $\mathrm{Mg} \mathrm{Kg}^{-1}$ & 95.6 \\
Available (P) & $\mathrm{Mg} \mathrm{Kg}^{-1}$ & 11.4 \\
Available (K) & $\mathrm{Mg} \mathrm{Kg}^{-1}$ & 114.2 \\
Sand & $\mathbf{G m ~ k g m}^{-1}$ & 150 \\
Silt & $\mathbf{G m ~ k g m}^{-1}$ & $\mathbf{4 6 0}$ \\
Clay & $\mathbf{G m ~ k g m}^{-1}$ & 390 \\
Soil texture & - & Silty clay loam \\
\hline
\end{tabular}

Table 2. Experiment treatments

\begin{tabular}{|c|c|c|}
\hline Code & Treatment & Additions \\
\hline T1 & Control & No additions \\
\hline $\mathbf{T 2}$ & Recommended Mineral fertilizer & $\begin{array}{c}\mathrm{N}\left(40 \mathrm{~kg} . \mathrm{ha}^{-1}\right)+\underset{\mathrm{P}_{2} \mathrm{O}_{5}\left(80 \mathrm{~kg} \cdot \mathrm{ha}^{-1}\right)}{\left.\mathrm{kg} . \mathrm{ha}^{-1}\right)}+\mathrm{K}_{2} \mathrm{O}(40 \\
.\end{array}$ \\
\hline T3 & Vermicompost only (1) & Vermicompost ( 8 ton. ha $\left.^{-1}\right)$ \\
\hline T4 & Vermicompost only (2) & Vermicompost (16 ton. ha $^{-1}$ ) \\
\hline T5 & Vermicompost only (1) + Rhizobia & Vermicompost $\left(8\right.$ ton. ha $\left.^{-1}\right)+$ Rhizobia \\
\hline T6 & Vermicompost only (2) + Rhizobia & Vermicompost (16 ton. ha $^{-1}$ ) +Rhizobia \\
\hline T7 & $\begin{array}{c}\text { Vermicompost only }(1)+1 / 2 \text { Recommended } \\
\text { Mineral fertilizer }\end{array}$ & $\begin{array}{l}\text { Vermicompost only }\left(8 \text { ton. } \text { ha }^{-1}\right)+1 / 2 \\
\text { Recommended Mineral fertilizer }\end{array}$ \\
\hline T8 & $\begin{array}{c}\text { 1/2 Recommended Mineral fertilizer + } \\
\text { Rhizobia }\end{array}$ & $\begin{array}{c}\text { 1/2 Recommended Mineral fertilizer + } \\
\text { Rhizobia }\end{array}$ \\
\hline T9 & $\begin{array}{c}\text { Vermicompost only }(1)+1 / 2 \text { Recommended } \\
\text { Mineral fertilizer }+ \text { Rhizobia }\end{array}$ & $\begin{array}{c}\text { Vermicompost only }\left(8 \text { ton. } \text { ha }^{-1}\right)+1 / 2 \\
\text { Recommended Mineral fertilizer }+ \\
\text { Rhizobia }\end{array}$ \\
\hline
\end{tabular}

Table 3. Some properties and elements contained in vermicompost

\begin{tabular}{|c|c|c|c|c|c|c|c|c|c|c|c|c|}
\hline \multirow{2}{*}{$\mathrm{EC} \mathrm{dsm}{ }^{-1}$} & \multirow{2}{*}{ pH } & \multicolumn{6}{|c|}{$\%$} & \multirow{2}{*}{$\mathbf{C} / \mathbf{N}$} & \multicolumn{4}{|c|}{ mgkg-1 } \\
\hline & & $\mathrm{C}$ & $\mathbf{N}$ & $\mathbf{P}$ & $\mathbf{K}$ & $\mathbf{C a}$ & Mg & & $\mathbf{F e}$ & Zn & Mn & $\mathbf{C u}$ \\
\hline 5.2 & 7.1 & 24 & 1.9 & 1.4 & 0.9 & 1.8 & 0.6 & 12.6 & 850 & 87 & 135 & 38 \\
\hline
\end{tabular}

\section{RESULTS AND DISCUSSION}

\section{Soil characters:}

The effect of experiment treatments on $\mathrm{pH}$, EC, CEC, O.M, total nitrogen, available phosphorus and potassium for soil after planting were present in Table 4 . It is clear from the table that the addition of vermicompost and rhizobia significantly reduced soil $\mathrm{pH}$ compared with the addition of mineral fertilizers only. The T6, T9, and T4 treatments were the best by giving $\mathrm{pH} 7.18$, 7.20 and 7.20 respectively, while there were no significant differences between the other treatments themselves. Is may due to the decomposition of vermicompost with the presence of rhizobia resulting in the formation of some organic acids as a result of decomposition and increased activity of microorganisms, and this in agreements with finding of Al-Rukabi (6), Alwan(8), Edwards (11) and Margit (19). The addition of vermicompost and rhizobia resulted in a decrease in soil salinity (EC) especially for the T6 and T9 treatments, which gave 2.20 and $2.25 \mathrm{dsm}^{-1}$ compared to the control and mineral fertilizer treatments $\mathrm{T} 1$ and $\mathrm{T} 2$ which gave 2.55 and $2.48 \mathrm{dsm}^{-1}$. The addition of vermicompost and rhizobia inoculums reduces soil salinity due to improved physical, biological and Soil fertility properties and increased plant growth that absorbs many 
elements during its growth period of this is agree with Maie et al. (17), Meena et al.(21) and Mehdi et al. (22), The results indicate a significant increase in CEC values by increasing the level of vermicompost addition, especially with rhizobia inculums (Table 4), T6 and T9 were significant the highest values of 47.9 and 46.2 Cmole $\mathrm{Kg}^{-1}$, respectively, Whereas, the control treatment $\mathrm{T} 1$ and mineral fertilization $\mathrm{T} 2$ recorded the lowest CEC of the soil, 22.6 and 23.0, respectively. These results were in agreement with Abosedera et al. (2), Hossein et al (13) and Manivannan et al. (18) who mentioned that the addition of vermicompost to the soil could reach the exchange capacity to 200 Cmole $\mathrm{Kg}^{-1}$ and increase the activity of microorganisms that decompose organic matter worked to increase soil CEC. The results in Table 4 show an increase in the ratio of organic matter, total nitrogen, available phosphorus and potassium in the soil after planting as a result of adding both vermicompost and rhizobia separately or both together. Treatments T6, T9 and T4 recorded a significant superiority with the highest values for the organic matter ratio, $2.90,2.80$ and $2.71 \%$ respectively, compared to $\mathrm{T} 1$ and $\mathrm{T} 2$, which gave the lowest percentage, which was 1.30 and $1.37 \%$, respectively. The T9 and T6 treatments also recorded the highest total nitrogen of 195.6 and $193.8 \%$, significantly superior to all other treatments, while $\mathrm{T} 1$ and $\mathrm{T} 2$ recorded the lowest total nitrogen ratio of 71.4 and $95.7 \%$. Likewise, with a concentration of available phosphorous and potassium, the T9 and T6 treatments recorded the highest significant mean of phosphorus 27.8 and $26.9 \mathrm{mg} \cdot \mathrm{kg}^{-1}$ and potassium 189.1 and 185.2 mg.kg-1, respectively. While the treatments $\mathrm{T} 1$ and $\mathrm{T} 2$ recorded the lowest concentration of phosphorous is 10.2 and $14.3 \mathrm{mg}-1 \mathrm{~kg}$ and for potassium is 103.5 and 125.7 mg. $\mathrm{kg}^{-1}$, respectively. It became clear that the addition of vermicompost, especially at the level of 16 ton $\mathrm{ha}^{-1}$, especially with rhizobia bacteria, had a significant positive effect in increasing the proportions of organic matter and total nitrogen, as well as the available phosphorus and potassium in the soil after planting, this is due to the properties of vermicompost and rhizobia, which affact to increase the availability of the nutrients in the soil by improving the active, chemical and biological properties in the soil, as well as through the liberation of the materials and nutrients that vermicompost contains when decomposed by microorganisms, in addition to that vermicompost leads to the formation of organic acids and stimulates the efficiency of the beneficial microorganisms and lowers the soil $\mathrm{pH}$, all of these factors will increase the dissolution of the compounds of the fixed or precipitating elements and thus increase their availability in the soil and the plant. Also, the presence of the vermicompost with rhizobia and its stimulation of microorganisms will work to produce growth regulators and enzymes, and these all work to increase the organic matter and elements ready for the plant, especially the macro-nutrients such as $\mathrm{N}, \mathrm{P}$ and $\mathrm{K}$. These results were agree with the findings of Aung et al. (10), Mahmoud et al. (16) and Parveen et al. (25).

Table 4. Effect of treatments on some soil properties after planting

\begin{tabular}{|c|c|c|c|c|c|c|c|}
\hline Treatments & pH & $\begin{array}{c}\text { EC } \\
\text { ds m-1 }\end{array}$ & $\begin{array}{c}\text { CEC } \\
\text { Cmole Kg }^{-1}\end{array}$ & $\begin{array}{c}\text { O.M } \\
\%\end{array}$ & $\begin{array}{c}\text { Total } \mathbf{N} \\
\%\end{array}$ & $\begin{array}{c}\text { P Av. } \\
\text { mg.kg-1 }\end{array}$ & $\begin{array}{c}\text { K Av. } \\
\text { mg.kg-1 }\end{array}$ \\
\hline T1 & 7.50 & 2.55 & 22.6 & 1.30 & 71.4 & 10.2 & 103.5 \\
\hline T2 & 7.45 & 2.48 & 23.0 & 1.37 & 95.7 & 14.3 & 125.7 \\
\hline T3 & 7.25 & 2.32 & 39.4 & 2.10 & 125.9 & 20.2 & 152.5 \\
\hline T4 & 7.20 & 2.30 & 43.6 & 2.71 & 168.2 & 24.3 & 168.4 \\
\hline T5 & 7.24 & 2.31 & 39.7 & 2.66 & 177.6 & 21.1 & 155.8 \\
\hline T6 & 7.18 & 2.20 & 47.9 & 2.90 & 193.8 & 26.9 & 185.2 \\
\hline T7 & 7.26 & 2.33 & 41.8 & 2.24 & 127.2 & 23.1 & 155.6 \\
\hline T8 & 7.28 & 2.37 & 37.2 & 2.15 & 160.8 & 22.4 & 148.2 \\
\hline T9 & 7.20 & 2.25 & 46.2 & 2.80 & 195.6 & 27.8 & 189.1 \\
\hline $\mathbf{L S D}_{\mathbf{0 . 0 5}}$ & 0.12 & 0.14 & 3.8 & 0.15 & 11.4 & 2.4 & 15.3 \\
\hline
\end{tabular}

\section{Growth characters:}

The T9 and T6 treatments showed a significant difference in the vegetative characters over the other of the treatments, as they recorded 70.1 and $68.7 \mathrm{~cm}$ for plant height, 54.2 and 51.8 $\mathrm{dm}^{2}$ plant $^{-1}$ for the leaf area, 62.1 and 56.7. gm plant $^{-1}$ for vegetative fresh weight' respectively (Table 5). While the $\mathrm{T} 1$ and $\mathrm{T} 2$ treatments showed the lowest value of the mentioned traits, they were 45.8 and $56.6 \mathrm{~cm}$ 
for plant height, 25.6 and $32.8 \mathrm{dm}^{2}$ plant $^{-1}$. for the leaf area, ad 26.4 and 38.0 gm Plant $^{-1}$ for the vegetative fresh weight, respectively. In addition, the T9 and T6 treatments showed best characteristics of the root system, as the highest significant difference was recorded over the rest of the treatments for each of the root lengths ( 27.8 and $27.3 \mathrm{~cm}$ ), root dry weight ( 6.2 and $5.6 \mathrm{~g} \mathrm{plant}^{-1}$ ), and the total root number of nodes (42.6 and 41.3 nodes plant $^{-1}$, and the number of effective root nodes (38.3 and 36.6 nodes plant ${ }^{-1}$. While the treatments $\mathrm{T} 1$ and $\mathrm{T} 2$ showed the lowest values of the root system traits (Table 5). The reason could be that the vermicompost fertilizer works to improve the physical, chemical, fertility and biological properties of the soil, as well as increase the availability of the nutrition's necessary for the plant, organic matter and useful microbial activity in the soil, which led to increased vegetative and root growth of the mung bean. The rhizobium inoculums form root nodules in the roots of plants that increase nitrogen fixation and then an increase in the amount of nitrogen added to the soil with the amount of nitrogen fertilizer added with bacterial inoculation, which also led to an increase in the root and vegetative characteristics of the plant. bacterial inoculation stimulates the plant to produce growth regulators, especially the indole acetic acid (IAA) and gibberellins, which encourages the division and elongation of cells. Nitrogen also has an important role in increasing the synthesis of chlorophyll and then increasing the process of photosynthesis and production of proteins of great importance in stimulating plant growth. This is confirmed by Abul-Soud et al. (3), Al- Dulimi a et al (4), Anshu et al. (9), Mahmoud et al. (16) Mehdi et al. (22) and Seyyed et al. (26).

\section{Yield, Root and quality characters:}

The addition of vermicompost, especially at the level of 8 tons ha- 1 with rhizobia and half of the recommended mineral fertilizer represented by the T9 treatment, as well as, the treatment of 16 tons ha $^{-1}$ with rhizobia only, represented by the treatment $\mathrm{T} 6$, gave the highest significant rate of number of pods per plant (51.0 and 49.6 pod plant $^{-1}$ ), respectively, and the highest mean weight of pods per plant ( 92.4 and $86.2 \mathrm{gm} \mathrm{plant}^{-1}$ ), respectively. The highest significant mean of 1000 seeds weight ( 49.8 and $48.7 \mathrm{gm}$ ), and the highest significant total (1216.95 and $\left.1135.60 \mathrm{~kg} \mathrm{ha}^{-1}\right)$ respectively, and the highest protein percent ( 29.5 and $28.3 \%$ ) compared to the rest of the other treatments. While control treatment T1 and chemical fertilization treatment alone $\mathrm{T} 2$ gave the lowest rates for the previously mentioned traits, 11.6 and 29.0 pod plant $^{-1}$, 44.6 and $60.3 \mathrm{gm} \mathrm{plant}^{-1}$ for the weight of the pods of the plant, 28.2 and 38.4 gm for weight 1000 seeds, 710.45 and $820.52 \mathrm{~kg} \mathrm{ha}^{-1}$ for total yield, and 16.4 and $18.6 \%$ for protein percentages, respectively. Addition of vermicompost, especially at the level of 16 tons $\mathrm{ha}^{-1}$ with rhizobium inoculums, has very important effects on plant and soil characteristics. Vermicompost had activity the physical properties of the soil, especially soil composition, water retention capacity and cationic exchange capacity. It also improves the chemical and fertility properties by increasing the availability of the nutrients in the soil and making them available to the plant either by dissolving the compounds of these elements and liberating them from the organic acids that it produces upon decomposition, or by the release of these elements from the vermicompost itself as a result of its decomposition and their release into the soil. Vermicompost also stimulates the biological state of the soil by stimulating the growth and effectiveness of microorganisms and their positive effects on plant growth by fixation of some elements such as atmospheric nitrogen or by dissolving and release some of the precipitated or fixed elements such as phosphorus and potassium

Presences of rhizobia with vermicompost, It attaches to the roots of the leguminous plant and produces nodules, these nodules fix atmospheric nitrogen and convert it into ammonia that can be used by the plant for its growth and development, as it interact with other microorganisms by improving plant growth by producing stimulants, growth regulators and enzymes and improving the quantitative and qualitative characteristics of the yield as an increase in the percentage of protein in Mung bean seeds. These results were consistent with that of AL-Dulimi et al (5), Anshu et al. (9), Muhammad et al (16), 
Maqshoof et al. (20), Mondal et al. (23),

Parveen, Aung et al. (25) and Seyyed et al.

(26).

Table 5. Effect of treatments on some properties of vegetative and root system of Mung bean

\begin{tabular}{|cccccccc|}
\hline Treatments & $\begin{array}{c}\text { Plant } \\
\text { height cm }\end{array}$ & $\begin{array}{c}\text { Leaf Area } \\
\text { dm }^{2} \\
\text { plant }^{-1}\end{array}$ & $\begin{array}{c}\text { Veg. Fresh } \\
\text { wt } \\
\text { gm. } \\
\text { plant }^{-1}\end{array}$ & $\begin{array}{c}\text { Root } \\
\text { length } \\
\text { cm }\end{array}$ & $\begin{array}{c}\text { Root } \\
\text { weight gm } \\
\text { plant }^{-1}\end{array}$ & $\begin{array}{c}\text { Total } \\
\text { nodes }_{\text {plant }}{ }^{-1}\end{array}$ & $\begin{array}{c}\text { Total effective } \\
\text { nodes plant }^{-1}\end{array}$ \\
\hline T1 & 45.8 & 25.6 & 26.4 & 14.6 & 2.9 & 12.6 & 8.3 \\
T2 & 56.6 & 32.8 & 38.0 & 18.2 & 3.3 & 15.3 & 9.6 \\
T3 & 60.5 & 43.2 & 42.4 & 20.9 & 3.8 & 20.0 & 13.0 \\
T4 & 63.4 & 48.7 & 48.8 & 24.5 & 4.7 & 26.6 & 20.0 \\
T6 & 64.9 & 47.5 & 48.3 & 24.1 & 4.4 & 37.0 & 32.3 \\
T7 & 68.7 & 51.8 & 56.7 & 27.3 & 5.8 & 41.3 & 36.6 \\
T8 & 63.2 & 47.9 & 45.8 & 23.5 & 4.3 & 24.0 & 19.0 \\
T9 & 62.9 & 45.4 & 43.2 & 23.0 & 4.1 & 34.6 & 29.6 \\
\hline
\end{tabular}

Table 6. Effect of treatments on yield characters of Mung bean

\begin{tabular}{|c|c|c|c|c|c|}
\hline Treatment & $\begin{array}{c}\text { Total pods per } \\
\text { plant }\end{array}$ & $\begin{array}{c}\text { Pods weight per } \\
\text { plant }\end{array}$ & $\begin{array}{c}1000 \text { seed } \\
\text { weight }(\mathrm{gm})\end{array}$ & $\begin{array}{c}\text { Seed yield } \\
\text { Kg.ha }^{-1}\end{array}$ & $\begin{array}{c}\text { Protein } \\
\%\end{array}$ \\
\hline T1 & 11.6 & 44.6 & 28.2 & 710.45 & 16.4 \\
\hline T2 & 29.0 & 60.3 & 38.4 & 820.52 & 18.6 \\
\hline T3 & 36.3 & 66.8 & 39.8 & 894.76 & 19.8 \\
\hline T4 & 40.0 & 75.2 & 42.3 & 925.68 & 24.9 \\
\hline T5 & 43.3 & 78.0 & 43.5 & 970.83 & 25.2 \\
\hline T6 & 49.6 & 86.2 & 48.7 & 1135.60 & 28.3 \\
\hline T7 & 38.6 & 71.5 & 42.0 & 920.80 & 23.8 \\
\hline T8 & 41.6 & 76.1 & 43.2 & 930.75 & 24.1 \\
\hline T9 & 51.0 & 92.4 & 49.8 & 1216.95 & 29.5 \\
\hline $\mathbf{L S D}_{0.05}$ & 4.9 & 5.4 & 4.5 & 95.60 & 2.4 \\
\hline
\end{tabular}

\section{REFERENCES}

1.Abdollah, B., A. Parvaneh, A. Ganjeali and P. Mahdi. 2016. Effect of vermicompost on some morphological, physiological and biochemical traits of bean (Phaseolus vulgaris L.) under salinity stress. J. Plant Nutr. 39(6): 883-893.

2.Abosedera, F. A., N. S. Shafshak, A. S. Shams, M. A. Abul-Soud and M. H. Mohammed. 2015. The utilize of vermicomposting outputs in substrate culture for producing snap bean. Ann. Agric. Sci. 53(2): 139- 151.

3.Abul-Soud, M. A., M. H. Mohammed, Z. Y. Maharik, A. M. H. Hawash and M. S. A. Emam. 2018. The effect of plant density and vermicompost rate on snap bean yield in substrate culture. Middle East J. Agric. Res. 7(4):2077-4605.

4.Al-Dulaimi, N. H and M. A. Al-Jumaili. 2017. Response green beans to spray some Micronutrients and addition Organic fertilizer. The Iraqi Journal of Agricultural Sciences. 48 (2): $444-455$.

5.Al-Dulaimi, N. H. and M. A. Al-Jumaili. 2017. Effect spraying some micronutrients and addition Humic acid in traits of roots and leaves content of Nutrients in green beans. The Iraqi Journal of Agricultural Sciences. 48 (3): 660- 670.

6.Al-Rukabi, M. N. M and K. D. H. Al-Jebory. 2017. Response of green bean to nitrogen fixing bacterial inoculation and molybdenum. The Iraqi Journal of Agricultural Sciences. 48 (2): 413-421.

7.Alper, D., A. Ozlem, K. Ibrahim, I. Rabia and K. Firat. 2017. The Effects of vermicompost on yield and some growth parameters of lettuce. Turkish J. Agric. Food Sci. Technol. 5(12):1566-1570.

8.Alwan, U. A., H. M. Aboud and B. H. Majeed. 2016. Effect of bio fertilizers and salicylic acid on availability of some nutrients in soil and plant and some vegetative and production quality of beans irrigation with saline water. The Iraqi Journal of Agricultural Sciences. 47(1): 291- 302.

9.Anshu, S. and S. Sharma. 2013. Effect of microbial inocula on mixed solid waste composting, vermicomposting and plant response. Comp. Sci. Utilizat. 11(3): 190- 199. 
10.Aung, Z. H., S. M. Moh., K. M. Soe., K. Moe and T. Yamakawa. 2019. Effects of bio fertilizer produced from Brady rhizobium and Streptomyces griseoflavus on plant growth, nodulation, nitrogen fixation, nutrient uptake, and seed yield of mung bean, cowpea, and soybean. Agronomy. 9(2): 77-86. 11.Edwards, C. A. 2004. Earthworm Ecology. Second Edition. Soil Ecology Laporatory. The Ohio State University, Columbus, Ohio, U.S.A. pp: 424.

12.FAO. 2012. Grassland Index. A searchable catalogue of grass and forage legumes. FAO, Rome, Italy. pp: 12.

13.Hossein, M., F. Mohammad and S. Alireza. 2014. Effect of Vermicompost on plant growth and its relationship with soil properties. Intl. J. Farm Alli Sci. 3 (3): 333- 338.

14.Hussein, A., A. Ali, T. Khaliq, A. Ahmad, Z. Aslam and M. Asif. 2014. Growth, nodulation and yield components of mung bean (Vigna aponic) as affected by phosphorus in combination with rhizobium inoculation. Afr. J. Agric. Res. 9(30): 2319- 2323. 15.Javed, S. and A. Panwar. 2013. Effect of biofertilizer, vermicompost and chemical fertilizer on different biochemical parameters of Glycine max and Vigna mungo. Recent Res. Sci. Technol. 5(1):40- 44.

16.Mahmoud, M., K. Essawy and A. Doaa. 2015. Effects of vermicompost and water treatment residuals on soil physical properties and wheat yield. Inst. Agrophys. 29(2): 157164 .

17.Maie, H. M. A., Hanaa, A. Abo-Kora and H. M. Abeer. 2016. Effect of vermicompost and calcium silicate to reduce the soil salinity on growth and oil determinations of marjoram plant. Int. J. Chem. Tech. Res. 9 (5): 235- 262. 18.Manivannan, S., M. Balamurugan, K. Parthasarathi, G. Gunasekarn and L. Ranganathan. 2009. Effect of vermicompost on soil fertility and crop productivity- beans (Phaseolus Vulgaris). J. Environ. Biol. 30(2): 275- 281.

19. Margit, O. 2016. The effect of Vermicompost based growth substrates on
Tomato growth. Thai. J. Agric. Sci. 1(1): 3841.

20.Maqshoof, A., Z. A. Zahir, H. N. Asghar and M. Arshad. 2012. The combined application of rhizobial strains and plant growth promoting rhizobacteria improves growth and productivity of mung bean (Vigna radiata $\mathrm{L}$.) under salt-stressed condition. Ann. Microbiol. 62: 1321-1330.

21.Meena, R. S., Y. Dhakal, J. S. Bohra, S. P. Singh, M. K. Sing, P. Sanodiya and H. Meena. 2015. Influence of bioinorganic combinations on yield, quality and economics of mung bean. Am. J. Exp. Agric. 8(3): 159- 166. 22.Mehdi, Z., V. Abadi and A. Moridi. 2018. Comparison of vermiwash and vermicompost tea properties produced from different organic beds under reenhouse conditions. Int. J. Rec. Org. W. Agric. 7:25- 32.

23.Mondal, N. K., J. K. Datta and A. Banerjee. 2015. Integrated effects of reduction dose of nitrogen fertilizer and mode of biofertilizer application on soil health under mung bean cropping system. Comm. Plant Sci. 5(1): 15- 22.

24.Muhammad, A., S. Ahmed, J. N. Chauhdary and M. Sarwar. 2016. Research article effect of vermicompost and phosphorus on crop growth and nutrient uptake in mung bean. J. Appl. Agric. Biotechnol. 1(2): 38-47. 25.Parveen, F. R., A. Embrandiri, M. H. Ibrahim, V. Ghole, C. T. Lee and M. Abbaspour. 2018. Effects of different vermicompost extracts of palm oil mill effluent and palm-pressed fiber mixture on seed germination of mung bean and its relative toxicity. Env. Sci. Poll. Res. 25(36): 3580535810 .

26.Seyyed, V., R. Mahmoudi, M. Nasri and P. Azizi. 2016. The effect of different type of vermicompost organic fertilizer litter on quantitative, qualitative and biochemical characteristics of green mung bean (Vigna radiata $\mathrm{L}$.) in drought stress conditions in Varamin. Int. J. Adv. Biotechnol. Res. (IJBR). 7(4): 205-215. 